\title{
Joko Widodo's Digital Diplomacy: A Prospect and Challenge for Indonesia's Digital Diplomacy towards Middle Power
}

\author{
Sasha Syaifani \& Naaimatur Rofiani Qubba \\ Universitas Airlangga
}

\begin{abstract}
Indonesia is known as a country whose people massively use social media. It is currently one of the largest internet users in the world, especially social media. President of Indonesia, Joko Widodo, (famously called 'Jokowi') also tries to 'fit in' to the trend of social media across Indonesia. Jokowi has several social media accounts, including Facebook, Twitter, Instagram, and YouTube. He even publishes a lot of his works, including his meeting agenda with other states' leaders. Jokowi sometimes uploads some video blogs or 'vlogs' which some of them are collaborations with leaders of powerful countries, such as King Salman Abdul Aziz of Saudi Arabia, Emmanuel Macron of France, and many others. Therefore, the authors consider this as a great opportunity for Indonesia to start digital diplomacy. Through literature study, the authors will provide a broader analysis of prospect and challenge of Indonesia's digital diplomacy. The findings showed that digital diplomacy implemented by Jokowi has a good prospect albeit many challenges. Moreover, it was also discovered that this type of diplomacy could bring some threats to Indonesia.
\end{abstract}

Keywords: digital diplomacy, Joko Widodo, Indonesia, social media, politics

Indonesia dikenal sebagai negara pengguna media sosial dalam secara besar. Indonesia saat ini merupakan salah satu negara pengguna internet terbesar di dunia, khususnya pada sosial media. Presiden Indonesia saat ini, Joko Widodo, atau yang lebih dikenal sebagai Jokowi, juga mulai memasuki tren sosial media di Indonesia. Jokowi memiliki beberapa akun media sosial media seperti Facebook, Twitter, Instagram, dan YouTube. Ia juga memublikasikan banyak hasil karyanya, termasuk agenda pertemuan dengan beberapa pemimpin negara. Jokowi juga mengunggah beberapa video blog atau vlog dengan berkolaborasi bersama pemimpin negara berkuasa, seperti Raja Salman Abdul Aziz dari Saudi Arabia, Emmanuel Macron dari Perancis, dan masih banyak lagi. Penulis memandang bahwa hal tersebut merupakan kesempatan besar bagi Indonesia untuk memulai diplomasi digital. Melalui studi kepustakaan, penulis akan menyediakan analisis luas mengenai prospek dan tantangan dalam diplomasi digital tersebut.

Kata-kata kunci: diplomasi digital, Joko Widodo, Indonesia, media sosial, politik 
Digital diplomacy is one of the methods for state government to achieve national interests. Fergus Hanson defines it as the use of internet and new information communication technologies to help achieve diplomatic objectives' (detiknews 2017). Digital diplomacy applies both positive and negative impacts of the internet into the practice of diplomacy at the institutional and personal level (Manor 2016). Everyone involved in this method has a heavy load to be taken care of, due to the possible results it may bring and affect the state. According to Mouna (2000), diplomacy is also related to procedures and approaches to negotiate with other states as state's intention to improve its relationship with others. Besides, diplomacy can also be used to influence public's opinion to restrain governments of other states (Watson 1982). The success of diplomacy itself depends on the achievement of actors' objectives. No matter what happens in the future, international actors need to survive within the existing international system. Since globalization is happening and amplifying the development of information and technology, along with it, diplomacy has flourished into more varied types, including digital diplomacy. Digital diplomacy creates more possibility to discover varied opinion from foreign citizens; thus, diplomacy has become smarter, faster, lighter, and more linked in network. Many watchful eyes scrutinize world situations, so state government needs to carefully control their own policy shortcomings.

\section{Implementations of Digital Diplomacy}

One of the implementations of digital diplomacy can be seen during Nepal Earthquake on April 2015. Media around the world immediately published the news and continuously updated its development. As soon as the earthquake happened, India's Ministry of Foreign Affairs (MFA) spreads the news on Twitter, coordinated some consular aids to Indians residing in Nepal. Each piece of important information was broadcast, such as contact number of Indian embassy in Kathmandu, flights schedules, and some updates on search and rescue operations (Manor 2016). These contacts were substantially helpful to conduct faster evacuation. Another example is Finland which created a project to broaden its culture spread around the world with digital diplomacy. Along with it, Finland enhanced its national branding through Finland's national emoji application which is downloadable on App Store. Recognizing 
tremendous attention from mass media, Finland successfully disproved majority's opinion that this country is dark and isolated.

What makes digital diplomacy and previous types of diplomacy different is the simplicity to conduct diplomacy without having to be at the same place physically. Nevertheless, its impacts on the achievement of political objectives can't be denied. Lack of representation is not a concern for state nowadays. Manor (2016) gives an example from the case of US' Virtual Embassy in Tehran which was launched in December 2011. US expected this website to help them interact with Iranian citizens online, because United States (US) and Iran do not have any diplomatic relationship. Digital diplomacy enables actors to develop their relationship with others, albeit time and distance obstruction.

Meanwhile, for Indonesia, as seen on Table 1.0, it is currently placed $5^{\text {th }}$ for countries with the highest number of internet users (Internet World Stats 2017). Indonesia is ahead of Japan which is at the 6th place and Russia at the 7th place. It is rather interesting, because those two states had better technology development than Indonesia. One of the major factors is the massive population of Indonesia which significantly influences the number of internet users. However, Indonesia is still behind India which ranked $2^{\text {nd }}$. Hence, Indonesia should learn to optimize its digital platforms to achieve its foreign policy goals (Triwibowo and Martha 2017).

Table 1.0: Top Countries with Highest Number of Internet Users by June $30^{\text {rd }}, 2017$

$\begin{array}{llll}\# & \begin{array}{l}\text { Country/ } \\ \text { Region }\end{array} & \begin{array}{l}\text { Population } \\ \text { (est. 2017) }\end{array} & \begin{array}{l}\text { Internet User } \\ \text { (June 30, 2017) }\end{array} \\ 1 & \text { China } & 1,388,232,693 & 738,539,792 \\ 2 & \text { India } & 1,342,512,706 & 462,124,989 \\ 3 & \text { United States } & 326,474,013 & 286,942,362 \\ 4 & \text { Brazil } & 211,243,220 & 139,111,185 \\ 5 & \text { Indonesia } & 263,510,146 & 132,700,000\end{array}$




$\begin{array}{llll}6 & \text { Japan } & 126,045,211 & 118,453,595 \\ 7 & \text { Rusia } & 143,375,006 & 109,552,842 \\ 8 & \text { Nigeria } & 191,835,936 & 91,598,757 \\ 9 & \text { Mexico } & 130,222,815 & 85,000,000 \\ 10 & \text { Bangladesh } & 164,827,718 & 73,347, \text { ooo }\end{array}$

(Internet World Stats, 2017)

\section{Jokowi's Digital Diplomacy}

In order to adapt to the rapid social media trend in Indonesia, Joko Widodo, the president of Indonesia runs several social media accounts to get in touch with his people through internet portals. Joko Widodo, who is famously called Jokowi, has several social media accounts, including Twitter, Instagram, YouTube, and Facebook. The government, including Indonesian Ministry of Foreign Affairs and several governmental bodies also run their own websites and social media. Hence, for this research, the authors will analyze Jokowi's social media accounts, namely Twitter, Instagram, YouTube, and several government bodies' accounts and websites. The authors left Facebook out, because diplomacy pattern and contents uploaded on Twitter, Instagram, and YouTube are more interesting than the ones uploaded on Facebook.

Jokowi joined Twitter on September 2011 (@jokowi 2017a) but has been actively using the account as a President since June 2015 which is eight months after his inauguration. The account currently has 8.7 million followers, which is considered a massive number compared to Australian Prime Minister, Malcolm Turnbull, with 937.000 followers or popular Canadian Prime Minister, Justin Trudeau, with 3.71 million followers. By mid-October 2017, the account has had 774 posts and approximately 81 tweets contained Jokowi's overseas visits or another state's leader visits to Indonesia, statelevel summits, personal meeting with several state leaders as well as with non-governmental actors and multinational corporations. Jokowi often tweeted about his own presidential visits to several countries, including the meetings with South Korea's Park Geun- 
Hye, German's Angela Merkel, Russia's Vladimir Putin, United Kingdom's David Cameron, Netherland's Mark Rutte and many more. One of the most interesting moments on his twitter is when Australia's Prime Minister Malcolm Turnbull tweeted Jokowi to thank him and Jakartans for 'such warm welcome and good discussions about trade investment and jobs', and Jokowi replied the tweet with 'our pleasure, warm regards from Indonesia'. Additionally, Twitter recorded that Jokowi's tweets are often retweeted thousand times (for each tweet) which makes Jokowi joins an influential list of world leaders who communicate on Twitter for digital diplomacy (Jakarta Globe, 2014). According to Burson-Marsteller's Twiplomacy Study (2017), Jokowi ranked $10^{\text {th }}$ for the Top Ten Most Followed World Leaders 2017 along with the state leaders of United States, Turkey, India, UAE, and Vatican.

Aside from Twitter, Jokowi also has an Instagram account (@jokowi 2017b) which was launched on January 2016. By October 2017, the account has had 5.9 million followers. Some photos were already published in Twitter, but the Instagram account also uploaded some exclusive photos. One of the most interesting posts of the account is when Jokowi uploaded a photo of him sitting together with the President of the United States of America, Donald Trump, at G20 World Leaders Summit on July 8, 2017. The post's caption was "a discussion about cooperation with President of USA, Donald Trump. Sometimes serious, sometimes joking, but still productive." Trump also uploaded a picture of him and Jokowi and attached a link to the remarks of their conversation. But one thing that can't be found in Jokowi's Instagram is the pattern of 'tagging'; while his Twitter has 'mentioning' pattern. Overall, the achievement of Jokowi's Instagram account is better than his Twitter, as it ranked $5^{\text {th }}$ most-followed account of World Leaders (Murson-Masterller 2006), ahead of Queen Rania of Jordan, Russian Prime Minister Dmitry Medvedev, and many more. The account also ranked $4^{\text {th }}$ for the Most Interactive World Leaders on Instagram and $7^{\text {th }}$ for the Most Effective World Leaders on Instagram. According to Twiplomacy (2017), Jokowi places $3^{\text {rd }}$ for the Most Liked World Leaders on Instagram after India's Narendra Modi and USA's Donald Trump. Based on the number of likes and followers, it can be seen that Jokowi's Instagram account conduct many interactions with people.

Meanwhile, vlog (video-blog) via YouTube has been trending in 
Indonesia these past years. Jokowi also tries to adapt himself to this trend by signing up an account named 'Presiden Joko Widodo' and launched on May 28, 2016. It has gained 395,625 subscribers by October 2017. At first, the account uploaded several videos about the president's overseas visits and domestic jobs. However, the account started a trend of '\#JKWVLOG' (Jokowi's Vlog) on September 2016. Authors believe that \#JKWVLOG' trend has something to do with Jokowi's youngest son, Kaesang Pangarep, who started uploading several vlogs labeled as 'PILOK' on his own YouTube channel. Jokowi seems to be inspired by Kaesang and tries to set his own vlog label which became a hit, started from his very first vlog upload on him doing archery with Kaesang in Istana Bogor. There are 18 vlogs in total and four of them are related with other states' leaders.

The first foreign-states-related vlog was the interaction of Jokowi and King Salman of Saudi Arabia during King Salman's visit to Indonesia. The two-minutes and English-subtitled video displayed Jokowi's self-camera and his explanations that King Salman's visit was a reciprocal visit after Jokowi invited the King two years ago. The was also a historical moment as the last visit of the King of Saudi Arabia to Indonesia was 47 years ago. King Salman also expressed his happiness to visit Indonesia, because he considered Indonesians as noble brothers and sisters of Saudi Arabia. The video was closed by Jokowi's expectation that the visit will strengthen the relationship between Indonesia and the Kingdom of Saudi Arabia. Furthermore, the second state leaders related vlog exhibited Jokowi's meeting with Recep Tayyip Erdogan, President of Turkey, during Jokowi's visit to Turkey. The video presented Erdogan calling Jokowi 'my brother' and his greeting to the citizens of Indonesia. Erdogan believed that the relationship between Indonesia and Turkey can be a model for the world. Jokowi also emphasized the significantlyclose relationship between both countries to the point that Jokowi often called Erdogan on phone. Meanwhile, the other two videos are related to Canadian Prime Minister, Justin Trudeau, and President of France, Emmanuel Macron. Trudeau emphasized that Indonesia and Canada were currently discussing several cooperation for Indonesia's better future; while Macron greeted Indonesian citizens and stated that he would visit Indonesia soon.

For Indonesia, digital diplomacy is considerably important to control problems concerning its citizens. Indonesian Ministry of Foreign 
Affairs also gave a special attention to this kind of diplomacy. For example, the ministry used a digital monitor to monitor Indonesia migrant workers in several countries. The government needs to ensure that these workers are not involved in any debauched issues, especially legal cases (Widjajajnto, et al 2013). Jokowi also uses digital diplomacy to broaden Indonesia's contribution to the world. Moreover, there are some foreign responses to Jokowi's publications related to Indonesia, though Jokowi's digital diplomacy might merely emphasize on domestic effects of the regime. It is because his posts, tweets, and YouTube videos are mostly addressed Indonesian citizens with Indonesian (and rare use of English). However, the authors conclude that King Salman's vlog (which is Englishsubtitled) shows Jokowi's intention to share with people around the world, not only with Indonesians. It is obvious that Jokowi is trying to show everyone that Indonesia is in a good term with the Kingdom of Saudi Arabia. The vlog did not only contain personal diplomacy, but also exhibits close relationship between Indonesia and Kingdom of Saudi Arabia, in which the King was even willing to collaborate in a vlog with Jokowi.

As for Turnbull's tweet to Jokowi on July, the tweet implicitly contains information that there was no problem between Indonesia and Australia. Both countries still maintain a good relationship and plan to make it stronger through cooperation. Jokowi stated that the two countries agreed to accomplish Indonesia-Australia Comprehensive Economic Partnership Agreement (IA-CEPA) at the end of 2017 (Tribun Jateng 2017). Triwibowo and Martha (2017) posited that using digital platforms for diplomacy in Jokowi's era as a detour from the old hierarchical diplomacy, because the audiences can feel closer to their leaders; hence, it changes the paradigm of old diplomacy on discretion and secrecy. While it is true that there has been no official clarification from Jokowi himself about using digital diplomacy, but the Minister of Foreign Affairs, Retno Marsudi, on her speech during Kompasianival in August 2016, highlighted the importance of digital instruments in today's diplomacy. The speech itself gained a new record from the State of Digital Diplomacy by Diplomacy.Live, a project which monitors sectoral use of internet and digital performance of state and non-state actors. Suci Lestari (as cited in Debora 2017), lecturer of the Department of International Relations at Universitas Gajah Mada, affirmed that using digital diplomacy will build a personal impression, as if there is no border 
between the president and his citizens and turn the citizens as witnesses of a bilateral cooperation.

\section{Challenges and Prospect}

Lestari also mentioned there are some challenges which must be faced by Jokowi's digital diplomacy. There must be a proof that anything in the vlog are not merely lip service. First, threats can emerge if Jokowi does not maintain this form diplomacy well. People will conclude Jokowi merely tries to project a certain image to the community, given the fact that the current generation tend to actively use social media and technology. If this kind of opinion was formed, it could be a boomerang for Jokowi and his team, because they receive negative results from Indonesian themselves. Obtaining negative views from society will cause various losses. One of such losses is to demand Jokowi administration to deliver the digital diplomacy more properly. Second, the threat could come from cybercrime. As Jokowi had several accounts on social media, Jokowi must learn that cybercrime may occur and emerge in various forms, but the first problem could occur due to some hackers. There is a possibility for Jokowi's account to be hacked by some hackers. Therefore, a quick response is needed as a preventive measure to protect the accounts from hacking. Moreover, Jokowi as a leader of Indonesia definitely has an added-value to attract hackers to hijack accounts. Imagine what could be obtained if the hackers were able to access Jokowi's accounts? Evidently, many advantages will be obtained by them. The third threat may occur if Jokowi shared too many posts, tweets, or videos which clearly exposes Indonesia's true intention. In international relations, one can never distinguish true color of state's intention. By sharing some information, achievement, or even vlog collaboration with other state leaders, Jokowi has indirectly opened up a bit of Indonesia's intention. Too much exposures make a country get tracked easily by its opponents. Even though Indonesia maintains a good image internationally (especially since the era of its previous president), the idea that no one could ever find out a state's real intention in international dynamics still holds. Indonesian behavior as a country which is reflected through Jokowi's post revealed that Indonesia has a decent level of technology and understands its progress. Additionally, excessive exposure may not be good, because other 
countries' leaders may give President Jokowi's attitude a different meaning. Therefore, Jokowi is expected to provide a clear post, not multi-interpretation and ambiguous ones; so as not to make Indonesia's position worse off in the international dynamics.

Indonesia has applied Politik Bebas Aktif, a policy made by Mohammad Hatta - the first Vice President of Indonesia - since September 1948. This policy means two things: Indonesia is free to build friendship with every single country without any pressure from other states; and Indonesia should always be active in the dynamics of international relations. Hence, Jokowi's digital diplomacy can also develop this policy more by employing technology to make friends and be active in international relations. Judging from the achievement and ranks of Jokowi's social media, the prospect of this type of diplomacy is observably good, if Jokowi strengthens and do not spoil too much information on it. However, Indonesia cannot be categorized as middle power if digital diplomacy is only employed by Jokowi. Every government body should also learn to use it. Additionally, it might be better to put English subtitle on digital contents, so that it is accessible for broader audience and in turn, build a good image of towards Indonesia. Indonesia as middle power means that it holds moderate influence and international recognitions. It implies that the existence of Indonesia might seem small for superpower countries, but Indonesia actually holds some power, such as massive internet users. As one of the biggest internet users in the world, it would be such a shame if Indonesia does not develop any digital diplomacies. By means, Jokowi's digital diplomacy is a good first-step for Indonesia to start its digital diplomacy journey. The prospect is promising for Indonesia as a whole and Jokowi himself. Moreover, digital technology is a new concept which has been used by other governments in some developed countries, albeit not officially stated. The ease offered by information technology should be utilized as much as possible by the people and the government of Indonesia to achieve middlepowership in international relations.

\section{Conclusion}

From the passage above, it can be concluded that diplomacy serves as a tool for the government to obtain national interests. Since Indonesia ranked $5^{\text {th }}$ as the country with massive internet users, 
President Jokowi tries to adapt to this phenomenon by running several social media accounts to get in touch with more people through internet portals. However, Jokowi's social media gradually also serves as one of foreign policy tools through digital diplomacy, not merely as a platform to maintain domestic affairs. Per joining Twitter on September, Jokowi had mentioned and been mentioned by several world leaders. On Instagram and Youtube, he also recorded some remarkable achievement. For instance, he started a vlog trend among government officials in Indonesia and also featured some world leaders in it. Digital diplomacy in Indonesia holds an utmost importance as a mean to control some problems concerning its citizens. Moreover, it leaves a lasting impression that Indonesia successfully maintains good relationships with other states, as shown by the personal featuring from some world leaders on Jokowi's vlogs, Twitter's mention, and Instagram posts. It also exhibits the new pattern of diplomacy unique to Jokowi's era.

However, it also poses some challenges to Jokowi to reveal the true nature of this diplomacy, whether he uses it merely as a tool of image-making or he sincerely attempts to build good relationships with other states. Additional threat also comes from cybercrime and over-spoiling information which can accidentally reveal Indonesia's true objective or intention in foreign relations. However, aside from those challenges and threats, Jokowi's digital diplomacy has set an example of innovation to maintain diplomacy through technological development. It can also serve as a new tool for Indonesia's fundamental principle of foreign policy, bebas-aktif. As a conclusion, Indonesia needs to maintain this digital diplomacy meticulously in order to enhance its position as middle power state in international relations. 


\section{References}

\section{Book}

Mouna, Boer, 2000. Hukum Internasional Pengertian, Peranan dan Fungsi dalam Era Dinamika Global. Bandung: Penerbit Alumni.

Watson, Adam, 1982. Diplomacy: The Dialogue Between State. London: Eyre Methuen. Widjajanto, Andi, et.al., 2013. Penataan Kebijakan Keamanan Nasional. Bandung: Dian Cipta.

\section{Journal and Online Journal}

Manor, Ilan, 2016. What is Digital Diplomacy and how is it Practiced around the World? A brief Introduction, [Online] http://www. academia.edu/30117350/What_is_Digital_Diplomacy_and_ how_is_it_P racticed_around_the_World_A_brief_introduction [accessed at October 24, 2017].

\section{Online Article}

@jokowi, 2017a [Online] Retrieved from http://www.twitter.com/ jokowi on October 17, 2017.

@jokowi, 2017b [Online] Retrieved from http://www.instagram. com/jokowi on October 17, 2017.

Burston-Marsteller, 2016. "World Leaders on Instagram: Full Study" [online] http://www.burson-marsteller.com/what-we-do/ our-thinking/world-leaders-on- instagram/world-leaders-oninstagram-full-study/ [accessed at October 21, 2017].

Debora, Yantina, 2017. “Vlog, Alat Diplomasi Baru Presiden Jokowi", Tirto.id [online] https://tirto.id/vlog-alat-diplomasibaru-presiden-jokowi-ckl9 [accessed at October 19, 2017].

detiknews, 2017. "Digital Diplomacy, Sebuah Kebutuhan Mendesak", [online]. https://news.detik.com/kolom/d-3194614/digitaldiplomacy-sebuah-kebutuhan- mendesak [accessed at October 24, 2017].

InternetWorldStats, 2017.“Top20 Countries with theHighestNumber of Internet Users" [online] http://www.internetworldstats. 
com/top20.htm [accessed at October 23, 2017].

Jakarta Globe, 2017. “Indonesia's First 'Twitter Election' Sets Record with Support of Jokowi" [online] Retrieved from http:// jakartaglobe.id/news/indonesias-first-twitter-election- setsrecord-with-support-for-jokowi/ [accessed at October 19, 2017].

Tribun Jateng, 2017. “Sebut Teman Dekat, Perdana Menteri Australia Unggah Video dan Foto Bareng Jokowi" [online] http://jateng. tribunnews.com/2017/07/08/ sebut-teman-dekat-perdanamenteri- australia-unggah-video-dan-foto-bareng-jokowi [accessed at October 23, 2017].

Triwibowo, A. and Martha, J., 2017. “Digital diplomacy: Learn from neighbors", The Jakarta Post [online] http://www. thejakartapost.com/academia/2017/08/25/digital-diplomacylearn-from- neighbors.html [accessed at October, 21 2017].

Twiplomacy.com, 2017. "Joko Widodo - President Joko Widodo" [online] http://twiplomacy.com/info/asia/indonesia/jokowi/ [accessed at October 21, 2017]. 